\title{
Peningkatan Kemampuan Berhitung Pada Anak Kelompok B Melalui Permainan Kartu Angka di TK Dharma Indria I Kecamatan Patrang Kabupaten Jember Tahun Pelajaran 2015/2016 The Increased Numerical Skill Of Children In Group B Through a Numerical Card Game In Dharma Indria I Kindergarten Patrang Jember 2015/2016 Academic Year
}

\author{
Qoyumil Hikmah, Misno A. Lathif, Khutobah \\ Jurusan Ilmu Pendidikan, Fakultas Keguruan Dan Ilmu Pendidikan, Universitas Jember (UNEJ) \\ Jln. Kalimantan 37, Jember 68121 \\ E-mail:misno.alathif@yahoo.com
}

\begin{abstract}
Abstrak
Penelitian ini dilaksanakan karena kegiatan pembelajaran di kelas yang masih belum efektif, akibatnya kemampuan berhitung pada anak kelompok B relatif belum baik. Tujuan penelitian ini adalah untuk meningkatkan kemampuan berhitung pada anak melalui permainan kartu angka. Jenis penelitian yang digunakan adalah penelitian tindakan kelas (PTK) yang dilaksanakan dalam dua siklus. Subjek penelitiannya adalah anak kelompok B berjumlah 30 anak yang terdiri atas 15 anak laki-laki dan 15 anak perempuan. Metode pengumpulan data yang digunakan adalah observasi, wawancara, tes dan dokumentasi. Hasil penelitian menunjukkan bahwa kemampuan berhitung pada ănak kelompok B mengalami peningkatan dengan kualifikasi sangat baik. Nilai rata-rata kelas pada pra siklus 58,3, pada siklus I 69,9, dan pada siklus II meningkat menjadi 82,7.
\end{abstract}

Kata Kunci: Kemampuan Berhitung, Permainan Kartu Angka.

\section{Abstract}

This research carried out because the learning activities in class fells less efective, as a consequence the math and numeracy ability on children in group B still didn't increassed well. The purpose of this research to increased the ability of children to learn math using card game. The type of research use in this study is research based on classroom action research (CAR) that conducted in two cycle. The subject on this reasearch is group $B$ children that has 30 member that separated into 15 boys and 15 girls. The method to coleected data in this reasearch is using observasion, interview, test, and documentation. The result of this research show that the ability to do aritmathic problem on the kid and group $B$ is increased with really good qualification, with avarage grade 58,3 on class in the pre-stage and 69,9 on the first stage and increased to 82,7 on the second stage.

Keywords: Arithmatic ability, Numerical card game

\section{Pendahuluan}

Anak usia dini merupakan saat yang sangat fundamental bagi kehidupan anak. Masa ini merupakan masa keemasan dimana anak mulai peka untuk menerima rangsangan dan otak mengalami pertumbuhan serta perkembangan yang angat pesat. Salah satu kemampuan anak yang sedang berkembang pesat saat usia ini adalah kemampuan kognitif khususnya kemampuan dalam berhitung. Kemampuan berhitung sangat penting bagi manusia, jadi perlu diajarkan sejak dini. Menurut Munandar [1], kemampuan berhitung merupakan daya untuk melakukan suatu tindakan sebagai hasil dari pembawaan dan latihan. Sejalan dengan perkembangan kemampuannya anak dapat meningkat ke tahap pengertian mengenai jumlah, yaitu yang berhubungan dengan penjumlah dan pengurangan.

Kemampuan berhitung adalah kemampuan yang dimiliki setiap anak untuk mengembangkan kemampuannya, karakteristik perkembangannya dimulai dari lingkungan terdekat dirinya [1].
Upaya peningkatan kemampuan berhitung anak dapat dikembangkan melalui berbagai kegiatan pembelajaran yang dapat memicu perkembangannya, salah satunya dapat dikembangkan melalui kegiatan yang berupa sebuah permainan yaitu permainan kartu angka. Bermain merupakan kegiatan yang sangat penting bagi pertumbuhan dan perkembangan anak [2]. Bermain bagi anak adalah eksplorasi, eksperimen, peniruan, dan penyesuaian. Bermain kartu angka berdampak positif terhadap peningkatan kemampuan berhitung karena dapat merangsang anak lebih cepat mengenal angka dan membuat minat anak semakin menguat dalam menguasai konsep bilangan [3].

Berdasarkan hasil observasi dan wawancara yang telah dilakukan, ditemukan bahwa kemampuan berhitung anak kelompok B masih rendah. Permasalahan tersebut muncul karena banyak anak yang masih belum mengetahui bagaimana cara menghitung penjumlahan dan pengurangan, kurang menariknya media yang digunakan oleh guru, serta dalam mengajarkan berhitung guru hanya menuliskan angkaangka di papan tulis dan anak menyalin tulisan tersebut pada 
buku masing-masing, sehingga anak menjadi pasif. Ini menyebabkan konsep berhitung kurang diserap dengan baik oleh anak. Sehubungan dengan permasalahan di atas, untuk mengatasi permasalahan tersebut, peneliti akan mengajarkan cara melakukan penjumlahan dengan mudah dan dapat dimengerti anak, dan juga akan memberikan suatu metode yang dapat dilakukan dalam pembelajaran berhitung yakni berupa permainan yang berupa permainan kartu angka, serta diharapkan mendapatkan hasil belajar yang memuaskan yakni kemampuan berhitung anak dapat meningkat dengan baik.

Rumusan masalah dalam penelitian ini adalah bagaimanakah meningkatkan kemampuan anak kelompok B dalam berhitung melalui permainan kartu angka di TK Dharma Indria 1 Kecamatan Patrang Kabupaten Jember tahun pelajaran 2015/2016?

Berdasarkan rumusan masalah tersebut maka tujuan penelitian ini adalah untuk meningkatkan kemampuan anak kelompok B dalam berhitung melalui permainan kartu angka di TK Dharma Indria I Kecamatan Patrang Kabupaten Jember tahun pelajaran 2015/2016. digunakan yaitu tes lisan dan tes tulis. Tes lisan berisi tanya jawab tentang mengenal angka 1-20. Tes tulis bertujuan untuk mendapatkan data hasil belajar anak dalam menulis angka 1-20, menulis penjumlahan dan pengurangan angka 120 pada anak kelompok B yang dilakukan saat pelaksanaan tindakan pada siklus I.

Metode dokumentasi dilakukan untuk memperoleh data secara konkrit yang digunakan sebagai sumber informasi dalam penelitian. Data-data tersebut di antaranya: (1) daftar nama siswa; (2) daftar nama guru; (3) profil sekolah; (4) rencana pelaksanaan pembelajaran harian (RPPH); (5) daftar hasil belajar siswa kaitannya dalam meningkatkam kemampuan berhitung, baik sebelum maupun sesudah dilakukan tindakan.

Analisis datanya dalah analisis data deskriptif kuantitatif dan kualitatif. Data deskriptif kualitatif diperoleh dari hasil wawancara sebelum dan sesudah tindakan, sedangkan data kuantitatif diperoleh dari hasil observasi, nilai perkembangan anak sebelum tindakan dan hasil belajar anak selama dilakukan tindakan pada setiap siklus.

Analisis kuantitatif peningkatan prestasi individu dihitung dengan rumus sebagai berikut:

$p i=\frac{\sum s r t}{\sum s i} \times 100$

Penelitian ini dilaksanakan di TK Dharma Indria I Jalan Jeruk No 10, Kecamatan Patrang, Kabupaten Jember pada semester genap tahun pelajaran 2015/2016. Subjek penelitian seluruh anak kelompok B TK Dharma Indria I berjumlah 30 anak, yang terdiri atas 15 anak laki-laki dan 15 anak perempuan.

Jenis penelitian ini adalah penelitian tindakan kelas
Keterangan:

pi : prestasi individual

srt : skor riil tercapai individu

si : skor ideal yang dapat dicapai individu

100 : konstanta

Masyhud [4]

(PTK). Teknis analisisnya deskriptif kualitatif dan Selanjutnya untuk mengetahui nilai rata-rata kelas maka kuantitatif. Rancangan penelitian ini terdiri atas empat tahap yaitu perencanaan, pengamatan, tindakan, dan refleksi. Metode pengumpulan datanya adalah metode observasi, wawancara, tes dan dokumentasi.

Metode observasi dilakukan untuk mendapatkan data secara langsung kegiatan pembelajaran di kelas. observasi dilakukan sebelum tindakan dan saat pelaksanaan tindakan. Observasi sebelum tindakan bertujuan untuk mengamati proses pembelajaran dalam meningkatkan kemampuan berhitung anak yang dilakukan oleh guru kelompok B. Selanjutnya observasi pada saat pelaksanaan tindakan dilakukan untuk mengetahui kegiatan guru dalam proses pembelajaran di kelas.

Metode wawancara dilakukan untuk mendapatkan data proses pembelajaran untuk meningkatkan kemampuan berhitung anak yang dilakukan guru selama ini. Wawancara dilakukan sebelum dan sesudah tindakan. Wawancara sebelum tindakan dimaksudkan untuk mengetahui peningkatan kemampuan berhitung anak yang dilakukan guru serta tanggapan guru tentang kegiatan yang dilakukan sebelumnya. Wawancara setelah tindakan dimaksudkan untuk mengetahui tanggapan guru tentang kegiatan pembelajaran yang telah dilakukan oleh peneliti.

Metode tes dipilih untuk mengukur seberapa jauh peningkatan hasil belajar anak. Metode tes bertujuan untuk mengetahui hasil belajar anak dalam peningkatan kemampuan berhitung pada kelompok B TK Dharma Indria I Kecamatan Patrang Kabupaten Jember Tahun Pelajaran 2015/2016 setelah tindakan dilakukan. Metode tes yang

\section{digunakan rumus sebagai berikut:}

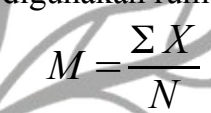

Keteran

M. Mean

$\sum X$ : Jumlah Nilai

$N$ : Banyak anak

Magsun [5]

Kriteria keberhasilan dalam penilaian kegiatan permainan kartu angka ditentukan berdasarkan hasil perolehan nilai setelah melakukan tes, baik perolehan hasil tes secara individu dan klasikal yaitu:

a) apabila nilai yang diperoleh anak kelompok B TK Dharma Indria I Kecamatan Patrang Kabupaten Jember tahun pelajaran 2015/2016 secara individu mencapai $\geq 70$, maka anak tersebut dapat dikatakan tuntas dalam pembelajaran kemampuan berhitung; dan

b) apabila nilai yang diperoleh suatu kelas mencapai $\geq 70$, maka pembelajaran kemampuan berhitung di kelas dapat dikatakan tuntas dan berhasil.

\section{Hasil dan Pembahasan}

Proses kegiatan permainan kartu angka dalam meningkatkan kemampuan berhitung anak kelompok B dilaksanakan dalam dua siklus. Pembelajaran pada siklus I guru menjelaskan tentang materi sesuai dengan tema yaitu 
gambar bendera Indonesia, guru menunjukkan gambar bendera kepada anak, selanjutnya guru melakukan tanya jawab tentang materi pembelajaran yang sudah dijelaskan kepada anak, setelah melakukan tanya jawab kepada anak guru mengajak anak untuk melakukan suatu permainan menggunakan kartu angka, guru menjelasakan bagaimana cara melakukan permainan tersebut dan memberi contoh, kemudian guru mengajak anak untuk melakukan permainan tersebut secara bergantian dan anak yang belum mendapatkan giliran mengerjakan tugas tentang berhitung yang sudah diberikan oleh guru sebelumnya. Anak mengerjakan tugasnya sampai selesai dan guru mengamati anak selama mengerjakan tugas. Hasil refleksi pada siklus I adalah masih ada anak yang belum mampu melakukan penjumlahan dan pengurangan, banyak anak yang ramai sendiri dan tidak mendengarkan guru, saat mengerjakan LKA masih ada anak yang meminta guru atau temannya untuk mengerjakan, dan alokasi waktu masih belum sesuai dengan RKH

Berdasarkan hasil refleksi pada siklus I maka dilakukan perbaikan pada siklus II. Perbaikan yang dilakukan yaitu guru mengajarkan bagaimana cara melakukan penjumlahan dan pengurangan, guru memberikan reward kepada anak yang mematuhi peraturan, guru memberikan reward kepada anak yang mau mengerjakan tugasnya sendiri, dan guru harus mengupayakan alokasi waktu yang digunakan sesuai dengan RKH. Berdasarkan hasil analisis dapat disimpulkan bahwa tindakan yang dilaksanakan pada siklus II berhasil dalam meningkatkan kemampuan berhitung anak kelompok B TK Dharma Indria I Kecamatan Patrang Kabupaten Jember Tahun Pelajaran 2015/2016. Hal ini dapat dilihat banyaknya anak yang tuntas dalam pembelajaran dengan nilai rata-rata kelas lebih baik dari pra-siklus dan siklus I.

Peningkatan kemampuan berhitung anak kelompok B TK Dharma Indria I Kecamatan Patrang Kabupaten Jember Tahun Pelajaran 2015/2016 setelah melakukan kegiatan berhitung dengan permainan kartu angka dapat dilihat dari ketuntasan belajar dan perolehan nilai rata-rata kelas pada pra siklus 58,3 dengan rincian 14 anak tuntas belajar dan sisanya 19 anak tidak tuntas belajar, dengan persentase $47 \%$ anak tuntas belajar dan 53\% anak tidak tuntas belajar. Setelah melakukan kegiatan berhitung dengan permainan kartu angka pada siklus I nilai rata-rata kelas meningkat menjadi 69,9 dengan rincian 19 anak tuntas belajar dan sisanya 11 anak tidak tuntas belajar, dengan persentase $63,3 \%$ anak yang tuntas belajar dan $36,7 \%$ anak tidak tuntas belajar. Selanjutnya pada siklus II nilai rata-rata anak meningkat lagi menjadi 82,7 dengan rincian 26 anak tuntas belajar dan sisanya hanya 4 anak yang tidak tuntas belajar, dengan persentase $86,7 \%$ anak tuntas belajar dan $13,3 \%$ anak belum tuntas belajar. Peningkatan hasil belajar anak dari pra siklus, siklus I dan siklus II disajikan pada Grafik 1 dibawah.

Berdasarkan grafik tersebut, tampak bahwa terjadi peningkatan pada ketuntasan belajar dan nilai rata-rata anak kelompok B TK Dharma Indria I Kecamatan Patrang Kabupaten Jember Tahun Pelajaran 2015/2016 secara klsikal pada siklus I dan siklus II.

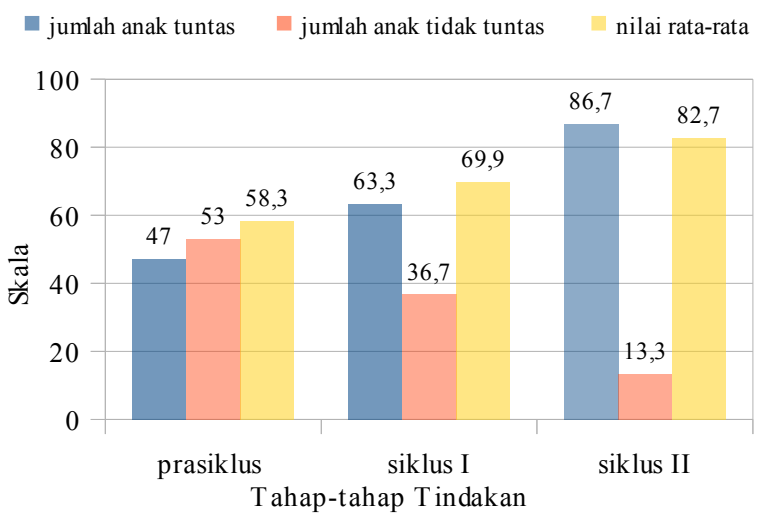

Gambar 1. Grafik perbandingan ketuntasan hasil belajar dan nilai rata-rata kelas.

Disimpulkan bahwa permainan kartu angka dapat meningkatkan kemampuan berhitung pada anak kelompok B TK Dharma Indria I Kecamatan Patrang Kabupaten Jember Tahun Pelajaran 2015/2016.

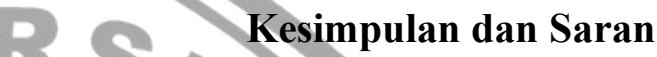

Melalui penerapan kegiatan permainan kartu angka nilai kemampuan berhitung anak kelompok B TK Dharma Indria I Kecamatan Patrang Kabupaten Jember Tahun Pelajaran 2015/2016 mengalami peningkatan. Keberhasilan tersebut dapat dilihat pada nilai rata-rata kemampuan berhitung anak pada siklus I 69,9 dan siklus II 82,78.

Berdasarkan kesimpulan di atas, dapat diberikan saransaran sebagai berikut: (1) Guru hendaknya memberikan permainan kartu angka untuk meningkatkan kemampuan berhitung anak sebagai salah satu alternatif dalam pembelajaran, (2) Kepala sekolah hendaknya memotivasi guru untuk menerapkan permainan kartu angka dalam proses pembelajaran berhitung supaya anak tidak bosan, (3) Kepala sekolah hendaknya memberikan fasilitas bagi guru dalam menerapkan suatu permainan kartu angka dalam pembelajaran, (4) Peneliti lain dapat dijadikan sebagai acuan dalam melaksanakan penelitian yang sejenis; dan hendaknya dapat dijadikan referensi untuk melakukan penelitian sejenis guna menambah wawasan.

\section{Ucapan Terimakasih}

Penulis mengucapkan terimakasih kepada pembimbing tugas akhir, serta teman dalam penelitian yang sama dan validator yang telah membantu dalam menyelesaikan peneitian ini.

\section{Daftar Pustaka}

[1] Susanto, A. 2011. Perkembangan Anak Usia Dini. Jakarta: Kencana Prenandamedia Group.

[2] Mutiah, D. 2010. Psikologi Bermain Anak Usia Dini. Jakarta. Prenada Media Group.

[3] Asiyah, S. 2012. "Penggunaan Media Kartu Angka Dalam meningkatkan Kemampuan Mengenal Konsep Bilangan Pada Anak Kelompok A". Tidak Diterbitkan. Skripsi. Surabaya: FKIP Universitas Negeri Surabaya.

[4] Masyhud, M. S. 2014. Metode Penelitian Pendidikan. Jember: Lembaga Pengembangan Manajemen Dan Profesi Kependidikan (LPMPK). 
[5] Magsun, H. , Sofwan, H , dan Lathif, Misno A. 1992. Pengantar Statistik Pendidikan. Jember: Universitas Jember.

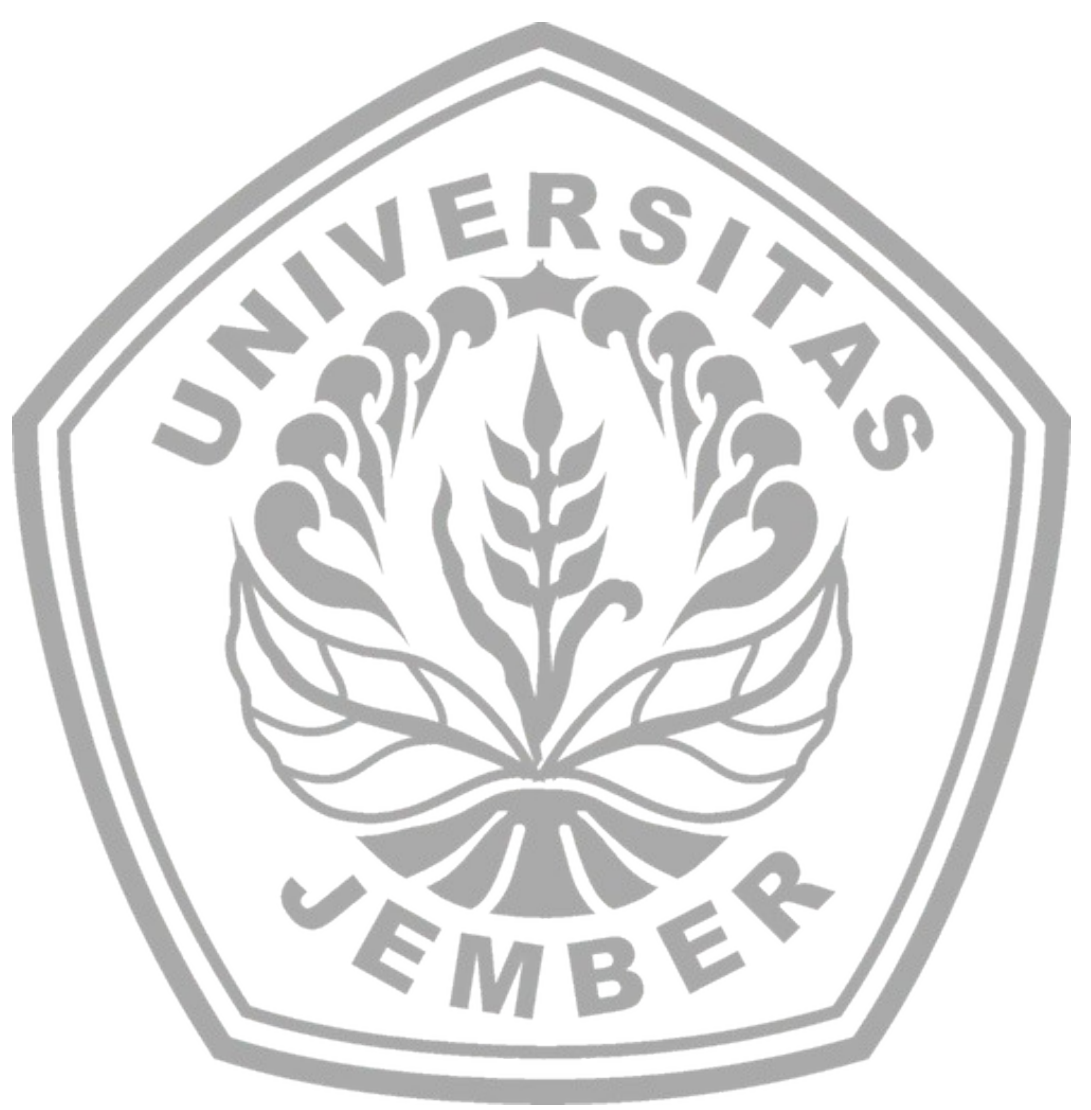

